American J. of Engineering and Applied Sciences 4 (4): 540-547, 2011

ISSN 1941-7020

(C) 2014 Kaewnai and Wongwises, This open access article is distributed under a Creative Commons Attribution

(CC-BY) 3.0 license

\title{
Improvement of the Runner Design of Francis Turbine using Computational Fluid Dynamics
}

\author{
${ }^{1}$ Suthep Kaewnai and ${ }^{1,2}$ Somchai Wongwises \\ ${ }^{1}$ Department of Mechanical Engineering, \\ Thermal Engineering and Multiphase Flow Research Lab (FUTURE), \\ Faculty of Engineering, King Mongkut's University of Technology Thonburi, \\ Bangkok 10140, Thailand \\ ${ }^{2}$ The Academy of Science, the Royal Institute of Thailand, \\ Sanam Suea Pa, Dusit, Bangkok 10300, Thailand
}

\begin{abstract}
Problem statement: The objective of this study is to improve runner design of the Francis turbine and analyze its performance with the Computational Fluid Dynamics (CFD) technique. Approach: A runner design process uses a direct method with the following design conditions: flow rate of $3.12 \mathrm{~m}^{3} / \mathrm{sec}$ head of $46.4 \mathrm{~m}$ and speed of $750 \mathrm{rpm}$ or dimensionless specific speed of 0.472 . Results: The first stage involves the calculation of various dimensions such as the blade inlet and exit angle at hub and the mean and shroud positions to depict the meridional plane. The second stage deals with the CFD simulation. Various results were calculated and analyzed for factors affecting runner's performance. Results indicated that the head rise of the runner at the design point was approximately $39 \mathrm{~m}$, which is lower than the specified head. Based on past experiences, the meridional plane was modified and blade inlet and lean angles were corrected. The process of meridional plane modification was repeated until the head rise was nearly equal to the specified head. Velocity vector and streamline should be a uniform stream. Conclusion/Recommendations: Results from calculating runner's performance were approximately $90 \%$ at design point. Existing absolute velocity component from CFD simulation pointed out that swirling flow occurred at the exit of runner. Based on the comparison of runner's performance between simulation results and experimental data from previous work reported in the literature, it is possible to use this method to simulate runner's performance of the Francis turbine.
\end{abstract}

Key words: Meridional plane, Francis turbine, runner, theoretical calculation, Best Efficiency Point (BEP), streamline

\section{INTRODUCTION}

Difficulty in construction of large dams to produce electricity leads to the study of the small turbine. Owing to the progress of the numerical method and computer capacity, a runner design of the Francis turbine can be analyzed by computer programs such as 3D-NavierStokes or CFD code to predict its performance before real production. Nevertheless, both the prediction and the design cannot be done easily without an existing database and past experiences. If results from the CFD predictions differ from the design, the turbine should be redesigned before real production. During the past decades, the Francis turbine was studied by many researchers.

Sebestyen and Keck studied flow in the Francis turbine at low head for EGLISU electrical plant
(Sebestyen and Keck, 1995). The runner design was improved to fit with existing casing and draft tube by analyzing with CFD technique. The efficiency was improved by $7 \%$ and its real efficiency was measured by $5 \%$ at design point.

Milos and Barglazan explained that the hydraulic runner design process for Francis turbine usually took a long duration, even for experienced designers (Milos and Barglazan, 2004). They proposed a streamline function of the flow through the runner to enable a quicker design process (Keck et al., 1996; 1997; Krishna, 1997; Vu and Shy, 1994; Wu et al., 2007).

\section{MATERIALS AND METHODS}

There are explanations for runner design processes and CFD prediction techniques, there is no available Corresponding Author: Suthep Kaewnai, Department of Mechanical Engineering, Thermal Engineering and Multiphase Flow
Research Lab (FUTURE), Faculty of Engineering, King Mongkut's University of Technology Thonburi, Research Lab (FUTURE), Faculty of
Bangmod, Bangkok 10140, Thailand 
data for one-dimensional hydraulic runner design, which is a starting point of the design process. Even though there is much research on the Francis turbine, there is still a large gap for further study. Therefore, this study focuses on the following main issues:

- Data for improvement of runner design

- Prediction of total head rise at various flow rates

- Checking of speed and streamline through the runner

- Checking of speed distribution along meridian plane at the runner inlet and outlet

- Checking of circumferential component at the absolute velocity to determine swirling flow at the runner outlet

Runner design process: In general, there are two approaches to runner design: the direct method and the inverse method. This study uses a direct method. Figure 1 show the runner design process that begins with the setting of Q (volume flow rate), $\mathrm{H}$ (head) and $\mathrm{n}$ (speed).

Basic equation in runner design: Basic theory in runner design assumes that flow occurs in one dimension. A momentum equation is applied to determine the runner's head Euler Eq. 1:

$\mathrm{H}=\frac{\mathrm{U}_{1} \mathrm{C}_{\mathrm{u} 1}}{\mathrm{~g}}$

The Free vortex used in the design assumes that head is static with no swirl at the runner blade outlet.

Dimensionless specific speed Eq. 2:

$v=\frac{\omega \sqrt{(\mathrm{Q} / \pi)}}{(2 \mathrm{gH})^{0.75}}$

Meridional component of absolute velocity Eq. 3:

$\mathrm{C}_{\mathrm{m}}=\frac{\mathrm{Q}}{\mathrm{A}_{\mathrm{v}}}$

Inlet or outlet area with blockage Eq. 4:

$\mathrm{A}_{\mathrm{v}}=\pi \mathrm{Db}-\mathrm{ZS}_{\mathrm{u}} \mathrm{b}$

Blade blockage Eq. 5:

$S_{u}=\frac{S}{\sin (\beta)}$

Average diameter Eq. 6:

$\mathrm{D}_{\text {ave }}=\frac{\mathrm{D}_{\text {hub }}+\mathrm{D}_{\text {shroud }}}{2}$

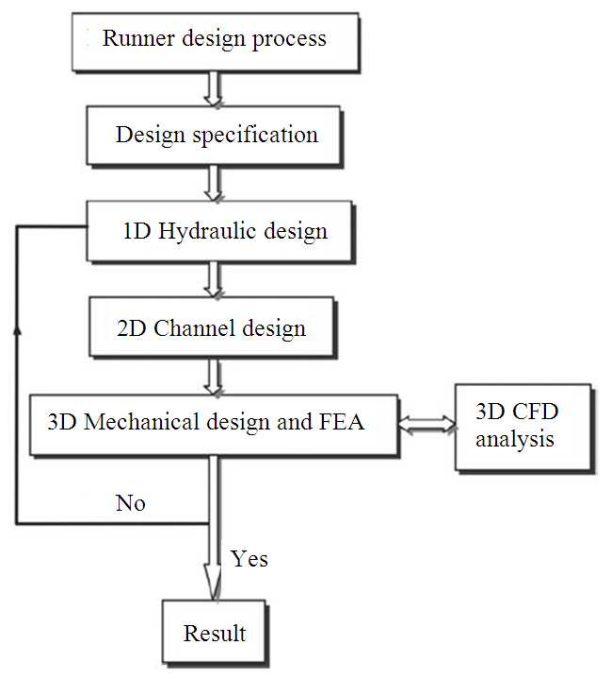

Fig. 1: Design process of runner

Circumferential speed Eq. 7:

$\mathrm{U}=\frac{\pi \mathrm{Dn}}{60}$

Basic mathematical equation of the model: This study uses CFX 5.5 software for three-dimensional flow. The fluid is incompressible and unsteady. The mass conservation and momentum equations for coordinate rotation system can be described as follows: Mass conservation Eq. 8:

$\frac{\partial \rho}{\partial \mathrm{t}}+\vec{\nabla} \cdot \rho \overrightarrow{\mathrm{V}}=0$

Momentum Eq. 9:

$\rho \frac{\mathrm{d} \overrightarrow{\mathrm{V}}}{\mathrm{dt}}+\vec{\nabla} \mathrm{P}=\rho \overrightarrow{\mathrm{g}}+\mu\left(\nabla^{2} \cdot \overrightarrow{\mathrm{V}}\right)-2 \rho \vec{\Omega} \times \overrightarrow{\mathrm{V}}-\rho \vec{\Omega} \times(\vec{\Omega} \times \overrightarrow{\mathrm{r}})$

Parameters for efficiency calculation: In CFD-code analysis, speed and pressure on the controlled surface at the runner's upstream and downstream could be determined by Eq. 10 .

Total head rise:

$\mathrm{H}_{\text {total }}=\left(\frac{\overline{\mathrm{P}_{1 \text { total }}}-\overline{\mathrm{P}_{2 \text { total }}}}{\rho \mathrm{g}}\right)$ 
Am. J. Engg. \& Applied Sci., 4 (4): 540-547, 2011

Table 1: Details at runner inlet

\begin{tabular}{lccc}
\hline Position & Hub & Mean & Shroud \\
\hline $\begin{array}{l}\text { Circumferential speed (m/sec) } \\
\begin{array}{l}\text { Circumferential component of } \\
\text { the absolute velocity (m/sec) }\end{array}\end{array}$ & 23.562 & 26.196 & 28.588 \\
\begin{tabular}{l} 
Blade angle (Degree) \\
\hline
\end{tabular} & 61.112 & 41.245 & 15.888 \\
\hline
\end{tabular}

Table 2: Details at runner outlet without preswirl

\begin{tabular}{llll}
\hline Position & Hub & Mean & Shroud \\
\hline Circumferential speed $(\mathrm{m} / \mathrm{sec})$ & 12.802 & 22.408 & 28.431 \\
Blade angle (Degree) & 30.22 & 18.109 & 14.697 \\
\hline
\end{tabular}

Table 3: Conditions used for the simulation

\begin{tabular}{ll}
\hline Parameters & CFD Code, CFX 5.5 \\
\hline Flow simulation domain & Single runner flow channel \\
Mesh & Structured \\
Fluid & Water at $25^{\circ} \mathrm{C}$ \\
Inlet & Total pressure \\
Outlet & Mass flow rate, Variable $(\mathrm{kg} / \mathrm{sec})$ \\
Wall & No slip \\
Turbulence model & $\mathrm{k}, \varepsilon$ \\
Maximum residual convergence & $10^{-4}(\mathrm{RMS})$ \\
\hline
\end{tabular}

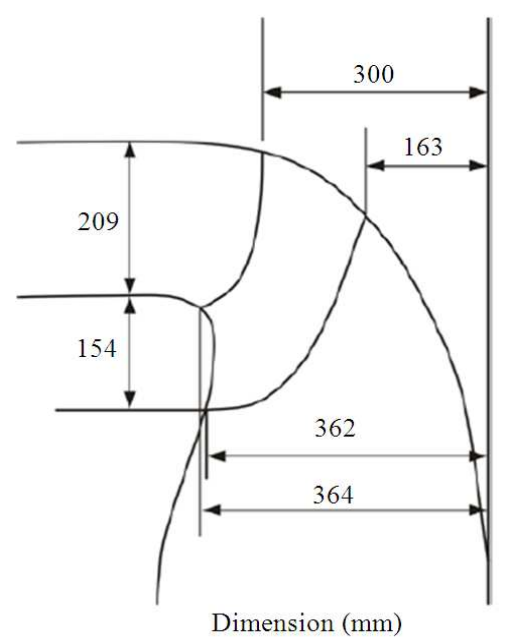

Fig. 2: Dimension of Francis turbine runner in meridional plane (Dimension: $\mathrm{mm}$ )

Theoretical head Eq. 11:

$\mathrm{H}_{\mathrm{th}}=\frac{\overline{\mathrm{U}_{1} \mathrm{C}_{\mathrm{u} 1}}-\overline{\mathrm{U}_{2} \mathrm{C}_{\mathrm{u} 2}}}{\mathrm{~g}}$

Runner efficiency Eq. 12:

$\eta_{\text {runner }}=\frac{\text { Total head rise }}{\text { Theoretical head }}$

Analysis of runner's flow: Analysis of the Francis turbine runner was done on the given design quantities: volume flow rate of $3.12 \mathrm{~m}^{3} / \mathrm{sec}$, head of $46.4 \mathrm{~m}$, circumferential speed of $750 \mathrm{rpm}$ or dimensionless specific speed of 0.472 and 11 blades of runner. The calculation shows that the Meridional component of the absolute velocity at the runner inlet, $\mathrm{C}_{\mathrm{m} 1}$ is $7.766 \mathrm{~m} / \mathrm{sec}$ and Meridional component of the absolute velocity at the runner outlet, $\mathrm{C}_{\mathrm{m} 2}$ is $7.457 \mathrm{~m} / \mathrm{sec}$. Various dimensions of the runner are shown in Fig. 2. Blade angle, circumferential speed and the circumferential component of the absolute velocity at the runner inlet and outlet could be summarized in Table 1 and 2 .

Dimension of runner in meridional plane is shown in Fig. 2. The analysis began with mesh generation and mesh refinement on runner domain. (The domain is the runner channel through which the fluid flows). Secondly, initial conditions and boundary conditions were specified for the mesh-refined domain. Finally, several calculations were made and displayed to determine factors affecting runner's performance. Results from CFD code included pressure; speed on $\mathrm{x}$, $\mathrm{y}$ and $\mathrm{z}$ axes and specific data that could be further analyzed. If the CFD code prediction gives incorrect results, the runner design can be corrected. Regarding the simulation using CFD code, the conditions used are shown in Table 3.

\section{RESULTS AND DISCUSSION}

Drafting domain of runner channel by 3D-CAD programs began as shown in Fig. 4. Then, the domain was entered into CFD code analysis to generate mesh, as shown in Fig. 5.

Analysis of simulation results: In this study, only the inlet and outlet of the fluid were considered to determine the effect on domain. To get better results, a finer mesh should be generated. Figure 6 shows the streamline distribution of the fluid and Fig. 7 shows the velocity distribution on the domain. Notably, the distributions are non-uniform. The results from simulation using CFD Code before improving the runner of Francis turbine are concluded in Table 4 and 5.

Runner design process: At the specified flow rate, results from simulation showed that the head rise was lower than specified head in the design:

- The design improvement process began by reshaping the meridian plane. The shape of the meridian plane is the first priority in designing fluid machinery that requires much experience. In Fig. 8, the shorter length of the meridian plane, compared to Fig. 3, does not signify the shorter length of the runner blade. The length of the runner blade depends on wrap angle $(\lambda)$, which is normally between $20-80$ degrees. 
Am. J. Engg. \& Applied Sci., 4 (4): 540-547, 2011

Table 4: Results from the simulation before runner improvement

\begin{tabular}{lcl}
\hline Mass flow rate & 3120 & $\mathrm{~kg} / \mathrm{sec}$ \\
\hline Volume flow rate & 3.12 & $\mathrm{~m}^{3} / \mathrm{sec}$ \\
Head rise & 39.00 & $\mathrm{~m}$ \\
\hline
\end{tabular}

Table 5: Results from simulation after runner improvement at design point

\begin{tabular}{lll}
\hline Mass flow rate & 3120 & $\mathrm{~kg} / \mathrm{sec}$ \\
\hline Volume flow rate & 3.12 & $\mathrm{~m}^{3} / \mathrm{sec}$ \\
Head rise & 46.3 & $\mathrm{~m}$ \\
\hline
\end{tabular}

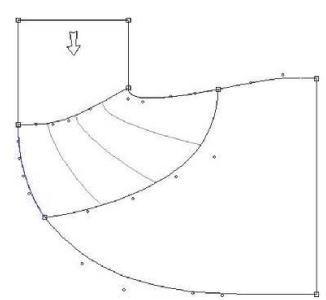

Fig. 3: Meridional plane of Fig. 2 corresponding to CFD Code

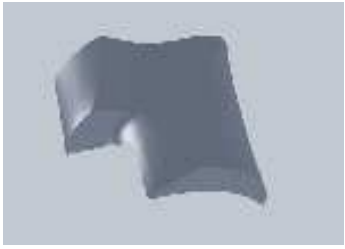

Fig. 4: Domain of runner channel

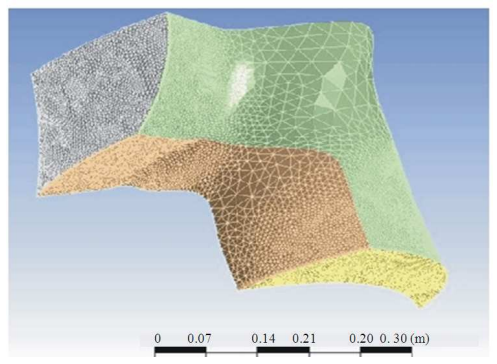

Fig. 5: Mesh on domain for numerical calculation

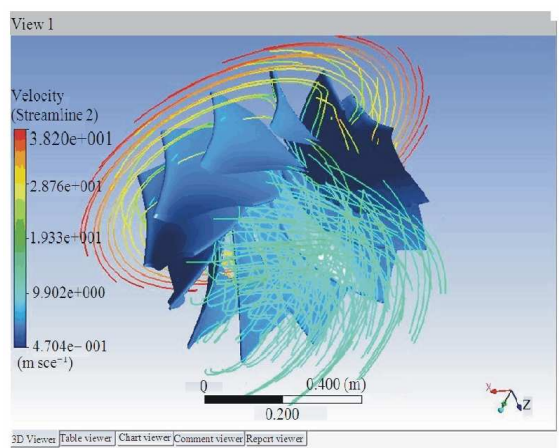

Fig. 6: Streamline distribution on runner

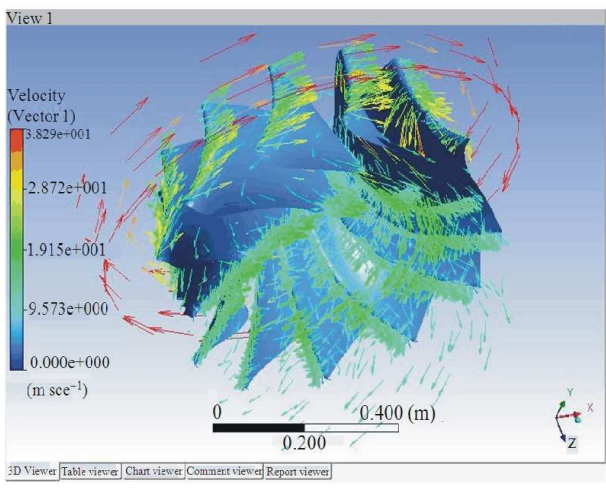

Fig. 7: Velocity distribution on runner

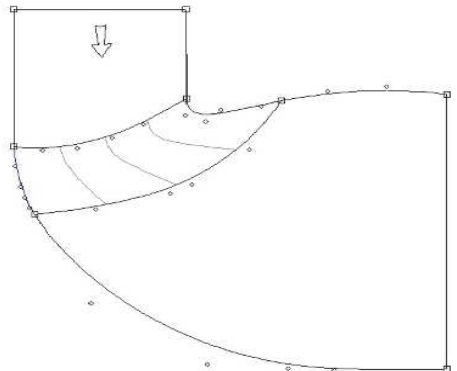

Fig. 8: Meridional plane after improvement

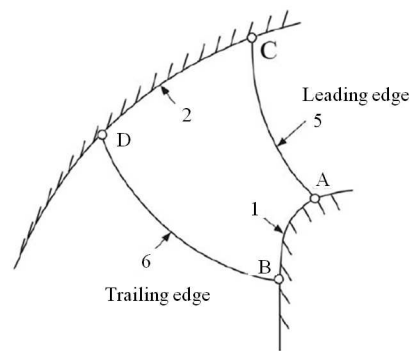

Fig. 9: Location of Meridional plane for Fig. 10

- Lean angle ( $\beta$ ) at runner blade inlet was adjusted to 10-30 degrees. Characteristic of lean angle is shown in Fig. 9-10

- Plan view of runner blade was adjusted as shown in Fig. 10

- Inlet angle of runner blade was adjusted to the value shown in Fig. 11. At the dimensionless specific speed 0.472 , the angles at the Hub and Shroud were changed to 64 and 73 Degrees, respectively. It is noticeable that the shroud angle is larger than the hub angle, which is contrary to the results from the theoretical calculation given in Table 1 
Am. J. Engg. \& Applied Sci., 4 (4): 540-547, 2011

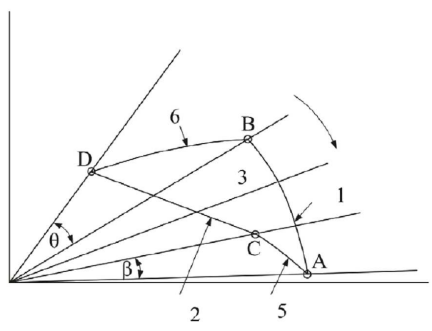

Fig. 10: Plan view of a runner blade

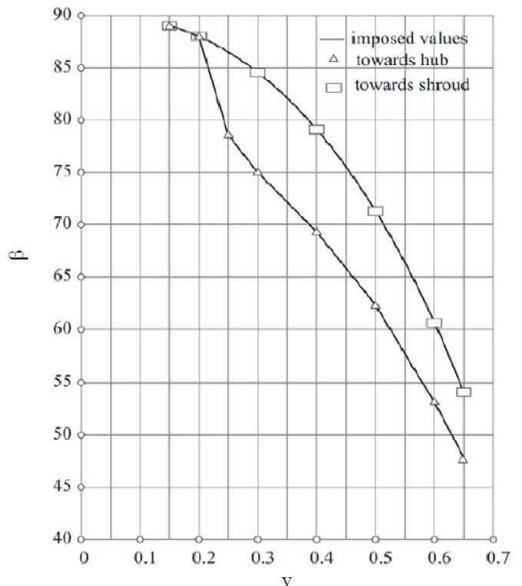

Fig. 11: Inlet and outlet angle of runner blade

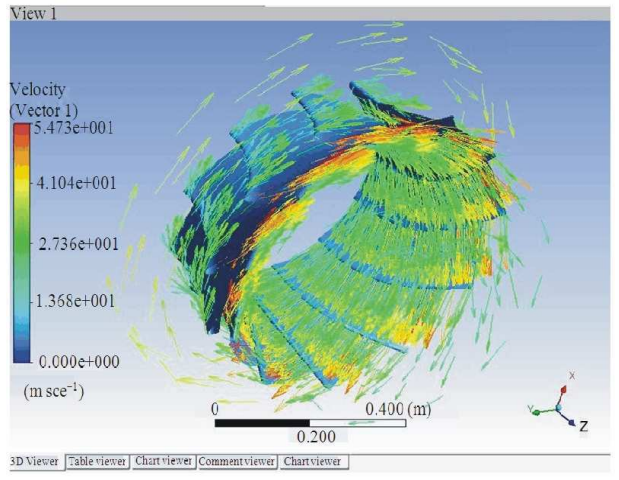

Fig. 12: Velocity distribution on runner after improvement

Results from runner design process: Figure 12 and 13 show that the velocity and streamline distributions on domain are uniform.

Runner performance: Runner performance from this study is shown in Fig. 14-17. Head rise at the specified design point is $46.4 \mathrm{~m}$. From Fig. 14, the head rise is $46.3 \mathrm{~m}$ at the same flow rate.

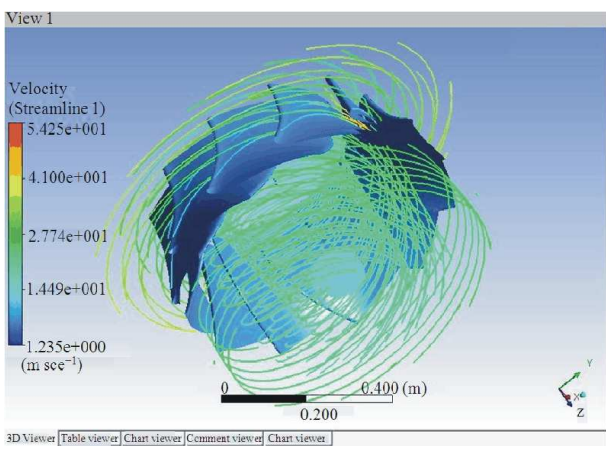

Fig. 13: Streamline distribution on runner after improvement

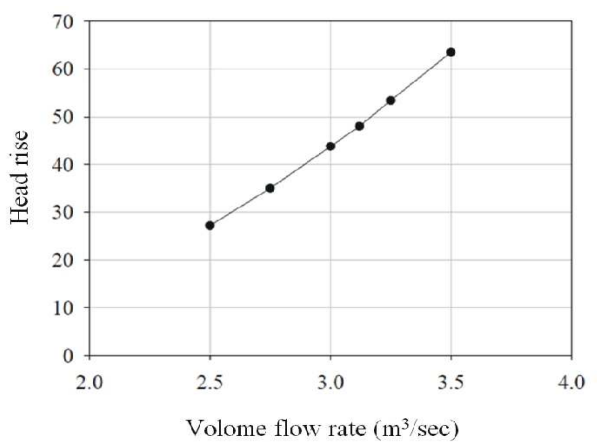

Fig. 14: Head rise Vs volume flow rate

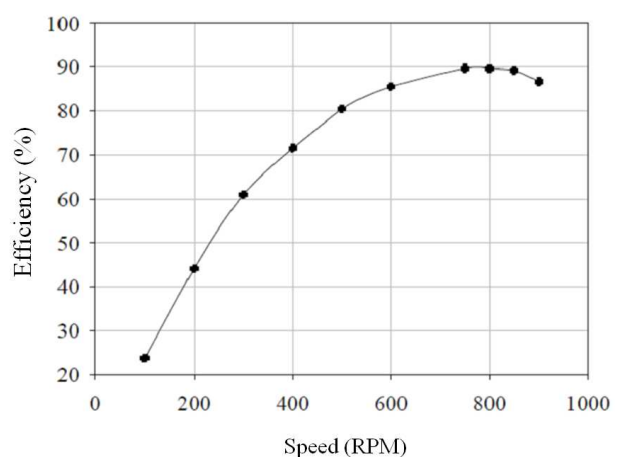

Fig. 15: Runner efficiency Vs speed

It could be seen that improvement of runner design leads to better head rise and head obtained from the simulation is close to the specified design point.

Figure 15 shows that, at the speed of $750 \mathrm{rpm}$, the runner's efficiency is $90 \%$. In real use, the runner is assembled with casing, draft tube and bearing; thus, the turbine's overall efficiency might be reduced because of friction. Figure 16 shows a relationship between head rise and speed. 
Am. J. Engg. \& Applied Sci., 4 (4): 540-547, 2011

It is found that at the designed speed, the head rise that has occurred is not the maximum head, which should be rotated at $400 \mathrm{rpm}$.

Figure 17 shows the speed of the meridian plane from CFD code from hub to shroud. One notices that the speed of meridian plane is maximum at the hub and minimum at the shroud, with an average of 6.931 $\mathrm{m} / \mathrm{sec}$. This differs slightly from the value gained from theoretical calculation.

Figure 18 shows that the circumferential component of the absolute velocity, at the runner inlet decreases from hub to shroud. Figure 19 shows that the speed of the meridian plane at the runner outlet is nearly stable.

Figure 20-21 show that the circumferential component of the absolute velocity at the runner outlet and distance from Hub is not equal to zero.

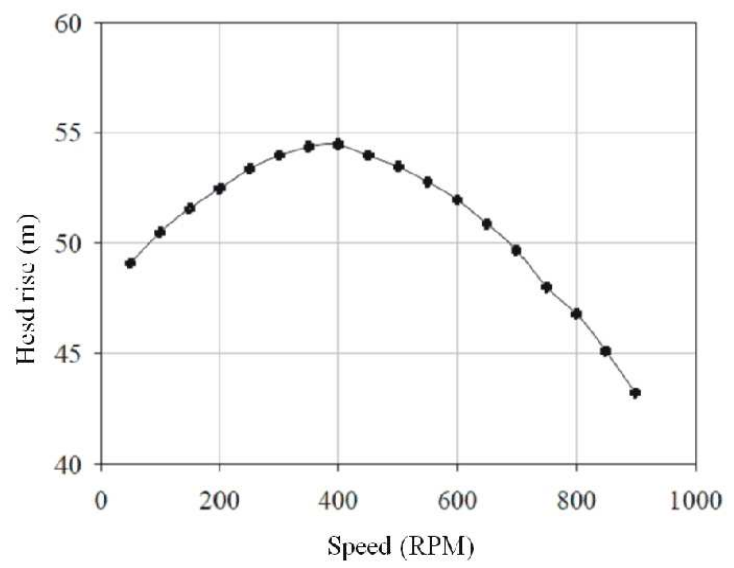

Fig. 16: Head rise Vs speed

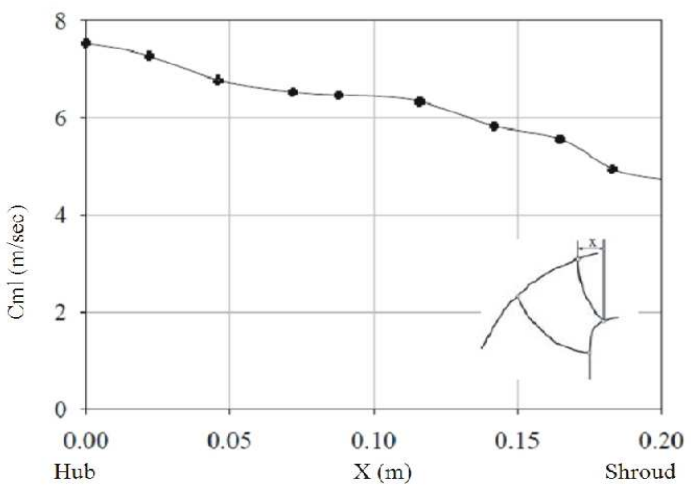

Fig. 17: Variation of meridional component of the absolute velocity at runner inlet with distance from hub

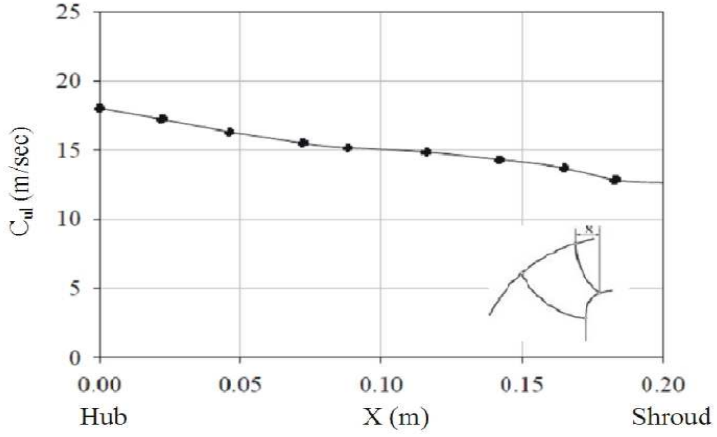

Fig. 18: Variation of circumferential component of the absolute velocity at runner inlet with distance from hub

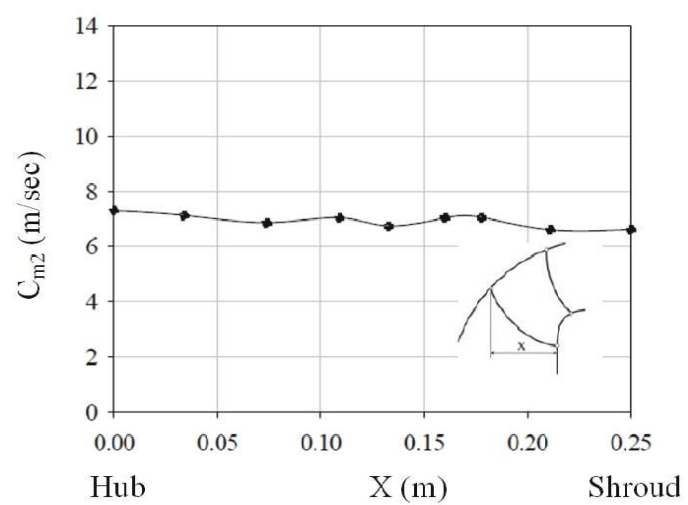

Fig. 19: Variation of meridional component of the absolute velocity at runner outlet with distance from hub

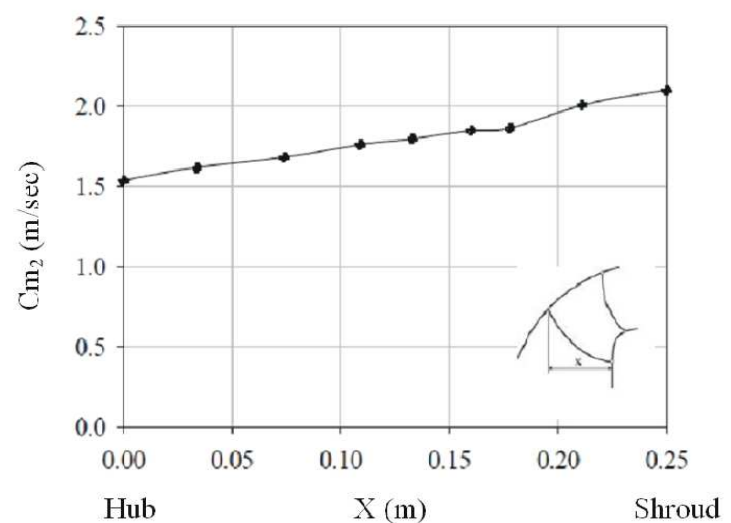

Fig. 20: Variation of circumferential component of the absolute velocity at runner outlet with distance from hub 


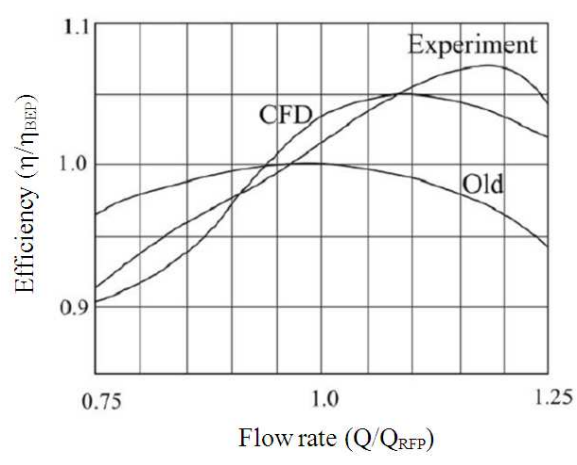

Fig. 21: Comparison between calculation and measurement; efficiency and volume flow rate referred to best efficiency point

This means that there is a pre-swirl at the runner outlet. Hence, the design that sets to zero is not correct.

Confirmation from CFD: This study did not conduct any experiment because of the high cost. However, the study by Sebestyen and Keck shows corresponding results between analysis and test (Sebestyen and Keck, 1995). The runner is redesigned for EGLISU electrical plant. CFD analysis indicated higher efficiency by $7 \%$. Then, the new runner was installed into the old casing and tested. It was found that the efficiency of the new runner-not including friction in casing, draft tube and bearing-was better by $5 \%$, close to results from CFD analysis. The highest point of efficiency was at.

\section{CONCLUSION}

The improvement of runner design of the Francis turbine to get the desired head rise and high efficiency relied on experienced correction of meridional plane and angle of runner blade inlet as shown in Fig. 11. It took a long time to complete this step. CFD analysis indicated that the runner efficiency at the design point was $90 \%$. At the flow rate close to the Best Efficiency Point (BEP), the runner's efficiency was quite high and became lower when the flow rate was far from the BEP. Checking the speed from CFD code revealed that the circumferential component of the absolute velocity at runner outlet was not equal to zero. Thus, the flow at the runner outlet caused swirl. However, the analysis only gave very small value. On the other hand, the meridional component of the absolute velocity at the runner outlet was nearly stable.

\section{ACKNOWLEDGMENT}

The researchers would like to express their appreciation to the Thailand Research Fund (TRF), the Office of Higher Education Commission and the National Research University Project for providing financial support for this study.

\section{List of symbols:}

\begin{tabular}{|c|c|}
\hline $\mathrm{A}_{\mathrm{v}}$ & Inlet or outlet area $\left(\mathrm{m}^{2}\right)$ \\
\hline $\mathrm{b}$ & Width of channel in the meridional section (m) \\
\hline $\mathrm{C}_{\mathrm{m} 1}$ & $\begin{array}{l}\text { Meridional component of the absolute velocity } \\
\text { at runner inlet }(\mathrm{m} / \mathrm{sec})\end{array}$ \\
\hline $\mathrm{C}_{\mathrm{m} 2}$ & $\begin{array}{l}\text { Meridional component of the absolute velocity } \\
\text { at runner outlet }(\mathrm{m} / \mathrm{sec})\end{array}$ \\
\hline $\mathrm{C}_{\mathrm{u} 1}$ & $\begin{array}{l}\text { Circumferential component of the absolute } \\
\text { velocity at runner inlet }(\mathrm{m} / \mathrm{sec})\end{array}$ \\
\hline $\mathrm{C}_{\mathrm{u} 2}$ & $\begin{array}{l}\text { Circumferential component of the absolute } \\
\text { velocity at runner outlet }(\mathrm{m} / \mathrm{sec})\end{array}$ \\
\hline CFD & Computational Fluid Dynamics \\
\hline $\mathrm{D}$ & Diameter $(\mathrm{m})$ \\
\hline FEA & Finite element analysis \\
\hline G & Gravitational acceleration $\left(\mathrm{m} / \mathrm{sec}^{2}\right)$ \\
\hline $\mathrm{H}$ & Design head of runner $(\mathrm{m})$ \\
\hline $\mathrm{H}_{\text {total }}$ & Total head rise \\
\hline $\mathrm{H}_{\mathrm{th}}$ & Theoretical head \\
\hline $\mathrm{K}$ & Turbulence kinetic energy \\
\hline $\mathrm{n}$ & Speed (rpm) \\
\hline $\mathrm{P}$ & Pressure $\left(\mathrm{N} / \mathrm{m}^{2}\right)$ \\
\hline $\mathrm{p}_{\mathrm{w}}$ & Power (Watt) \\
\hline $\mathrm{P}_{1 \text { total }}$ & Total pressure at runner inlet $\left(\mathrm{N} / \mathrm{m}^{2}\right)$ \\
\hline $\mathrm{p}_{2 \text { total }}$ & Total pressure at runner outlet $\left(\mathrm{N} \mathrm{m}^{2}\right)$ \\
\hline Q & Volume flow rate $\left(\mathrm{m}^{3} / \mathrm{sec}\right)$ \\
\hline $\mathrm{R}$ & Radius from the reference point (m) \\
\hline S & Blade thickness (m) \\
\hline $\mathrm{S}_{\mathrm{u}}$ & Blade thickness with blockage $(\mathrm{m})$ \\
\hline $\mathrm{U}_{1}$ & Circumferential speed at runner inlet $(\mathrm{m} / \mathrm{sec})$ \\
\hline $\mathrm{U}_{2}$ & Circumferential speed at runner outlet $(\mathrm{m} / \mathrm{sec})$ \\
\hline $\overrightarrow{\mathrm{V}}$ & Velocity vector $(\mathrm{m})$ \\
\hline $\mathrm{Z}$ & Number of blade \\
\hline$\beta$ & Blade angle \\
\hline$\eta$ & Efficiency \\
\hline$v$ & Dimensionless specific speed \\
\hline$\varepsilon$ & Turbulence eddy dissipation \\
\hline$\rho$ & Density of water $\left(\mathrm{kg} / \mathrm{m}^{3}\right)$ \\
\hline $\bar{\Omega}$ & Angular velocity ( $\mathrm{rad} / \mathrm{sec})$ \\
\hline $\bar{\nabla}$ & Operator \\
\hline
\end{tabular}


Am. J. Engg. \& Applied Sci., 4 (4): 540-547, 2011

\section{REFERENCES}

Keck, H., P. Drtina and M. Sick, 1996. Numerical hill chart prediction by mean of CFD stage simulation for a complete Francis turbine. Porceedings of the IAHR Symposium Hydraulic Machinery and Cavitation, (HMC' 96), Valencia.

Keck, H., P. Drtina and M. Sick, 1997. A breakthrough-CFD flow simulation for a complete turbine. Sulzer Hydro Ltd., Switzerland.

Krishna, H.C.R., 1997. Hydraulic Design of Hydraulic Machinery. 1st Edn., Avebury, Aldershot, ISBN: 0291398510, pp: 570.
Milos, T. and M. Barglazan, 2004. CAD technique used to optimize the francis runner design. Proceedings of the 6th International Conference on Hydraulic Machinery and Hydrodynamics Timisoara, Oct. 21-22, Politehnica University, Romania, pp: 125-130.

Sebestyen, A. and H. Keck, 1995. Uprating of ultralow francis units based on numerical flow analysis. Sulzer Hydro Ltd., Switzerland.

Vu, T.C. and W. Shy, 1994. Performance prediction by viscous flow analysis for francis turbine runner. $\mathbf{J}$. Fluid Eng., 116: 116-120.

Wu, J., K. Shimmei, K. Tani, K. Niikura and J. Sato, 2007. CFD-based design optimization for hydro turbines. J. Fluid Eng. ASME, 129: 159-168. 